\title{
POTRZEBA BLISKOŚCI I INTYMNOŚCI A ŚWIADOMOŚĆ NIEPEŁNOSPRAWNOŚCI
}

\begin{abstract}
Streszczenie: W artykule poruszony jest temat intymnych związków emocjonalnych młodych osób z niepełnosprawnością, opisane są pewne trudności w nauczeniu się prawidłowych relacji emocjonalnych z matką i innymi osobami w okresie wczesnego dzieciństwa. Nie pozostają one jednak w bezpośrednim związku z niepełnosprawnością, ale raczej stanowią wypadkową reakcji rodziców na nietypowe, i dlatego nie zawsze dla nich „czytelne”, reakcje emocjonalno-społeczne dziecka. Komunikaty emocjonalne dziecka są także mylnie interpretowane przez innych członków społeczeństwa, którego krąg rozszerza się w miarę rozwoju, a ta sytuacja przyczynia się do zaburzenia relacji emocjonalno-społecznych między osobą z niepełnosprawnością i jej otoczeniem. Jednak potrzeby emocjonalne są takie same u osób niepełnosprawnych i u pełnosprawnych, ale wobec opisywanych zaburzeń w relacji interpersonalnej nie zawsze mogą być zaspokojone. Dotyczy to zwłaszcza potrzeby bliskiego związku emocjonalnego z osobą płci przeciwnej w okresie dorastania i wczesnej dorosłości, kiedy tego typu potrzeby są szczególnie nasilone. Przestawione badania pokazują, że wielu młodych ludzi widzi rozwiązanie tego problemu w kontakcie i znajdowaniu partnera życiowego przez Internet.
\end{abstract}

Słowa kluczowe: niepełnosprawność, bliskość emocjonalna, potrzeby emocjonalne, trudności $\mathrm{w}$ relacjach interpersonalnych

Potrzeby człowieka, bez względu na jego stan fizyczny i psychiczny, należą do tego rodzaju właściwości człowieka, pod których wpływem powstają emocje: niezaspokojone potrzeby wywołują stan emocjonalny ujemny, subiektywnie odczuwany jako przykrość, a potrzeby zaspokojone są źródłem stanów emocjonalnych pozytywnych, subiektywnie odczuwanych jako przyjemność. Potrzeba bliskości i intymności należy do kategorii potrzeb psychicznych w odróżnieniu od bardziej 
podstawowych potrzeb biologicznych, od zaspokojenia których zależy przetrwanie organizmu w sensie biologicznym. Nie oznacza to jednak, że niezaspokojone albo zaspokojone potrzeby biologiczne nie wiążą się z przeżywaniem odpowiednich emocji (Garczynski 1972).

Emocje o znaku dodatnim są tymi, których pojawianie się i trwanie jest przez każdy organizm pożądane, ponieważ gwarantują poczucie bezpieczeństwa, a chęć ich wyzwalania ukierunkowuje działania poszukiwawcze. Ta zorientowana na osiąganie określonego celu aktywność jest siłą napędową wszelkich działań, u podłoża których leżą emocje. Jednakże celem może być sprowokowanie pozytywnego stanu emocjonalnego i wówczas są to działania zmierzające w określonym kierunku, ale mogą to też być działania, których celem jest oddalenie się od potencjalnego źródła emocji negatywnych. Siła ta staje się z czasem motywacją, która kieruje ludzkimi działaniami świadomie lub podświadomie, ale zawsze są to działania sterowane emocjonalnie. Mogą to być zachowania unikowe, działania zachowawcze albo ukierunkowane na osiągnięcie celu. Każdy rodzaj tak motywowanej aktywności powoduje - oprócz zaspokojenia poczucia bezpieczeństwa - powstawanie innych potrzeb pochodnych od potrzeb organicznych, ponieważ te drugie są zaspokajane w pierwszych miesiącach życia nie samodzielnie, lecz w kontekście interakcji społecznych i przez społeczeństwo. Najbardziej aktywnym „wykonawcą" działan skierowanych na zaspokojenie sygnalizowanych przez niemowlę potrzeb jest zazwyczaj matka, ale $\mathrm{z}$ czasem krąg realizatorów tych działań rozszerza się i do końca życia żaden człowiek nigdy nie jest na tyle samowystarczalny, aby bez udziału innych ludzi zaspokoić wszystkie swoje potrzeby. Co więcej, rozwój potrzeb jest ściśle związany z doświadczeniem społecznym i rozwojem społecznym, a związki te już w okresie późnego dzieciństwa są tak silne, że izolacja społeczna staje się źródłem bolesnych przeżyć wskutek niezaspokojenia potrzeby bliskości emocjonalnej. Okres dojrzewania i dalszy rozwój emocjonalno-społeczny jest uwarunkowany istnieniem pozytywnych relacji interpersonalnych i wyzwalających się na ich tle nowych potrzeb, wynikających z dojrzewania płciowego przy założeniu, że został już osiągnięty odpowiedni poziom dojrzałości emocjonalnej i społecznej.

\section{NIEPEENOSPRAWNOŚĆ I ZAGROŻENIE ZASPOKOJENIA POTRZEBY BLISKOŚCI}

Nie jest prawdą, że nieprawidłowości rozwojowe są bezpośrednim zagrożeniem życia uczuciowego, ale także nie można zaprzeczyć, że jakakolwiek nieprawidłowość rozwojowa czy niepełnosprawność nie mają żadnego odbicia w ewentualnych zaburzeniach rozwoju sfery emocjonalnej i społecznej. Jednakże każdy rodzaj 
zaburzenia rozwojowego czy niepełnosprawności niesie swoiste zagrożenia i dlatego nie można do tej kwestii ustosunkować się w sposób ogólny i jednoznaczny.

Wspólne dla wszystkich osób mających od urodzenia bądź wczesnego dzieciństwa problemy z prawidłowym funkcjonowaniem organizmu jest to, że mają one także potencjalne trudności w realizacji swoich potrzeb. Jednocześnie wspólna jest konieczność zaspokojenia potrzeb biologicznych, żeby w ogóle dziecko mogło żyć, ale także wspólna jest potrzeba zagwarantowania bezpieczeństwa, zaspokojenia więzi emocjonalnej z jedną i tą samą osobą w ciągu pierwszych trzech lat życia, a na bazie tych potrzeb rozwijają się inne potrzeby o charakterze emocjonalno-społecznym, jak potrzeba akceptacji, przynależności, uznania, osiągnięć i wiele innych wzajemnie od siebie uzależnionych. I tu pojawia się konieczność zróżnicowania na osoby, które nie mogą samodzielnie zaspokoić nawet swoich potrzeb biologicznych, a zaspokajanie ich przy pomocy innych osób także nie zawsze przynosi pozytywne rezultaty w postaci pożądanego stanu emocjonalnego i poczucia bezpieczeństwa, oraz na te, które po procesie rehabilitacji nauczą się być samodzielne w zakresie większości swoich potrzeb. Dodać należy, że niektóre osoby nie mogą i nigdy nie będą mogły realizować nawet biologicznych potrzeb tą samą drogą, jaka jest naturalna ze względu na ewolucyjnie wypracowane sposoby funkcjonowania organizmu.

Drugą niemniej ważną kwestią jest tworzenie więzi emocjonalnej matki (lub osoby pełniącej rolę biologicznej matki) z niemowlęciem. Kiedy dziecko rodzi się zdrowe, jego relacje z matką rozwijają się niemal automatycznie przez wzajemny kontakt, głównie wzrokowy. Początkowo matka jest inicjatorką pozytywnych doznań emocjonalnych dziecka przeważnie dzięki systematycznemu zapobieganiu pojawieniu się stanu niedoboru, czyli niezaspokojeniu potrzeb leżących u podłoża ujemnych stanów emocjonalnych, tym samym zaspokajając podstawową potrzebę psychiczną, jaką jest potrzeba bezpieczeństwa. Jest ona zwana w psychologii metapotrzebą, bo stanowi jednocześnie warunek wyzwalania się aktywności własnej niemowlęcia, a to z kolei jest właściwość będąca filogenetycznym wyposażeniem człowieka w chwili urodzenia i warunkująca gotowość do odbierania i reagowania na bodźce zarówno wisceralne, jak i zewnątrzpochodne.

Matka ponadto sama potrzebuje dowodów własnej więzi emocjonalnej z dzieckiem, prowokując niemowlę do odpowiadania na jej zaczepne zachowania: kontakt cielesny, wzrokowy, głosowy, zapachowy, smakowy. Każda - początkowo niespecyficzna - reakcja dziecka na matczyne bodźce jest przez rodzicielkę interpretowana pozytywnie i wyzwala u niej samej pozytywny stan emocjonalny, który stara się podtrzymywać i jak najczęściej powtarzać, a rolę inicjującą przypisuje życzeniowo dziecku. W ten sposób zaspokaja własną potrzebę więzi emocjonalnej ze swoim dzieckiem, ale jednocześnie uczy dziecko właściwych reakcji na bodźce społeczne, 
gratyfikując je za każdym razem emocjonalnie. Dziecko zdrowe i pełnosprawne już w ciągu pierwszych dni życia nawiązuje z matką emocjonalno-społeczną relację.

Nie można jednak tego samego powiedzieć o relacjach dziecka niepełnosprawnego z matką. Najtrudniej jest nawiązać kontakt wzrokowy matce z dzieckiem niewidzącym, co stanowi zagrożenie dla rozwoju pierwszych intymnych relacji, na podstawie których tworzy się ich więź emocjonalna. Problem ten wraz ze wskazaniem późniejszych zagrożeń rozwojowych i trudności w nawiązywaniu relacji międzyludzkich został opisany przez Joannę Konarską (2012).

W przypadku pozostałych rodzajów niepełnosprawności udaje się matkom nawiązać z niemowlęciem kontakt wzrokowy tak samo jak z dzieckiem pełnosprawnym, ale pojawiają się specyficzne dla każdego rodzaju niepełnosprawności problemy, które dotyczą bezpośrednio nie tyle dziecka, ile właśnie matki, a także innych osób mających częsty kontakt z dzieckiem. Od tych pierwszych relacji emocjonalnych niemowlęcia z najbliższymi mu osobami, jakimi są zazwyczaj rodzice, dziadkowie i rodzeństwo, zależy jakość późniejszych relacji interpersonalnych opartych na doświadczeniach z wczesnego dzieciństwa. Gdy dziecko jest pełnosprawne, reakcje na bodźce wzrokowe, słuchowe, dotykowe i - ze strony dziecka - również zapachowe powodują wymianę pozytywnych bodźców wzmacniających tendencje do częstego, intensywnego kontaktu. Powtarzalność sytuacji wzbudzających pozytywny stan emocjonalny dziecka powoduje zaspokojenie i jednocześnie wzmożenie potrzeby bezpieczeństwa. Jednak ze strony rodziców - zwłaszcza w pierwszych kontaktach matki z niepełnosprawnym niemowlęciem - może zabraknąć tego elementu wzajemnego wzmacniania pozytywnego stanu emocjonalnego. O ile dla dziecka każdy kontakt $z$ matką będzie dawał poczucie bezpieczeństwa i początkowo będzie źródłem pozytywnego stanu emocjonalnego, o tyle w matce kontakt $\mathrm{z}$ własnym dzieckiem może wzbudzać zarówno emocje pozytywne, typowe dla każdej matki, jak i negatywne, ponieważ nietypowe reakcje dziecka, ich brak, wygląd fizyczny różniący się od wyglądu innych niemowląt (zdeformowane ciało, zmieniony wygląd twarzy) sprawia jej ból, wywołuje niepokój o przyszłość dziecka, myśli o niespełnionych nadziejach związanych z macierzyństwem, poczucie bliżej nieokreślonej winy za stan zdrowia dziecka i w końcu lęk oraz bezradność wobec niewytłumaczonego zrządzenia losu. Taki stan matki absolutnie nie sprzyja intensyfikacji więzi emocjonalnych z dzieckiem opartych na radości z posiadania potomstwa i nadziei na jego wymarzoną przez rodziców przyszłość. Dziecko, nawet jeśli otrzymuje od matki wszystko, co związane jest z zaspokojeniem jego biologicznych potrzeb, nie dostaje odpowiednio dużej dawki bodźców, które pobudzają go do reakcji zwrotnej i tym samym rozwoju emocjonalno-społecznego. Oczywiście nie jest to kanon w relacjach rodziców z dzieckiem niepełnosprawnym, ale - przynajmniej w pierwszych miesiącach jego życia - poważne zagrożenie dla kształtowania się 
pozytywnych doświadczeń emocjonalno-społecznych w przyszłości. Istnieje sposób, aby tym zakłóceniom relacji zapobiec przez bardzo wczesną pomoc psychologiczną rodzicom, bowiem wraz z narodzinami niepełnosprawnego dziecka doświadczają oni bardzo głębokiego kryzysu psychicznego zamiast ogromnej radości i nadziei. Rodzice najbardziej dotkliwie odczuwają brak nadziei i niepokój lub wręcz lęk o przyszłość dziecka, a także bezradność wobec jego stanu. Odbija się to niekorzystnie na stanie emocjonalnym niemowlęcia, które empatycznie wyczuwa niepokój wokół siebie, co może skutkować dodatkowymi (oprócz tych związanych bezpośrednio z niepełnosprawnością) zakłóceniami jego zachowania. Reakcje dziecka natomiast wzmagają niepokój rodziców i utrudniają im ustabilizowanie własnego stanu emocjonalnego, a także uspokojenie dziecka. Sytuacja staje się trudna i samopobudzająca do dystansu emocjonalnego, a czasem fizycznego, matki w stosunku do dziecka: jest to podświadomy mechanizm obronny, ponieważ rzadszy kontakt fizyczny z dzieckiem chroni matkę przed przykrymi emocjami wyzwalanymi przez stan dziecka. W takiej sytuacji ani dziecko, ani matka nie mają szansy nawiązać satysfakcjonującego obie strony stosunku emocjonalnego (Konarska 2003).

Doznawanie od najwcześniejszego dzieciństwa dystansu emocjonalnego (jeśli nie całkowitego lub częściowego odrzucenia) prowadzi do wyuczenia się reakcji unikowych w stosunku do innych osób, ponieważ wczesne doświadczenia dziecka potwierdzały, że poczucie bezpieczeństwa i stabilizacja emocjonalna wiąże się nie $\mathrm{z}$ intensywnym, ale z ograniczonym kontaktem społecznym. Opierając się na doświadczeniach wyniesionych $\mathrm{z}$ domu rodzinnego, dziecko buduje potem relacje ze społecznością rówieśników oraz dorosłych. Nie jest to na ogół wrogość, ale nieufność i intuicyjne poczucie, że niemożność sprawiania sobie i innym radości przez bezpośrednią interakcję ma związek z niepełnosprawnością. Stąd już tylko krok do wartościowania siebie przez pryzmat niepełnosprawności, a jeśli do tego dochodzi zniekształcenie ciała, poczucie odrębności i niższej wartości może być jeszcze większe.

Złożona sytuacja społeczna dziecka niepełnosprawnego, które - tak jak inne dzieci - rośnie i potrzebuje kontaktu z rówieśnikami, w wyniku którego umacnia wiedzę o sobie samym i zdobywa określoną pozycję społeczną, najczęściej nie jest korzystna dla tych dzieci, które nie doznały dostatecznie silnego potwierdzenia własnej wartości przez okazywanie miłości przez rodziców i innych członków rodziny. Nie spodziewają się też niczego lepszego od innych osób w miarę rozszerzania kręgu społecznego, ale nauczone doświadczeniem starają się ograniczać relacje społeczne do niezbędnego minimum, znajdując poczucie bezpieczeństwa w takich formach aktywności, które nie wymagają bezpośredniego kontaktu (Konarska 2017).

Nie jest to oczywiście scenariusz rozwoju, który powinien być realizowany w przypadku dzieci z niepełnosprawnością ani właściwy sposób odnoszenia się 
rodziców do dziecka. Niestety, bez pomocy psychologicznej udzielonej rodzicom w chwili uzyskania informacji o niepełnosprawności dziecka, rodzicom bardzo trudno osiągnąć równowagę psychiczną i spełniać z radością swoją rodzicielską rolę wobec dziecka. Tym bardziej, że nie ogranicza się ona do wypełniania typowych obowiązków wobec dziecka: rodzice dzieci z niepełnosprawnością powinni umieć być nie tylko kochającymi, cierpliwymi rodzicami, ale także rehabilitantami świadomymi celowości swoich działań. Jest to zadanie bardzo trudne i bez profesjonalnej pomocy oraz bez wsparcia ze strony pozostałych członków rodziny nie zawsze możliwe do realizacji (Garczyński 1972; Kocowski 1982; Jundziłł 1998).

\section{OKRES DOJRZEWANIA I PRZEMIANY W ZAKRESIE POTRZEBY DOZNAWANIA BLISKOŚCI}

O ile stosunkowo rzadko natychmiastowa pomoc psychologiczna jest dostępna, o tyle w większości wypadków rodzice mogą liczyć na swoich rodziców, a z czasem na wsparcie innych osób i w rezultacie rzadko się zdarza, aby matka i dziecko przez dłuższy czas nie potrafili nawiązać satysfakcjonujących obie strony relacji emocjonalnych. To powoduje, że mimo niepełnosprawności większość dzieci osiąga normalny, porównywalny do pełnosprawnych rówieśników poziom rozwoju emocjonalno-społecznego i posiada takie same potrzeby oraz marzenia jak ich koledzy. Dotyczy to także okresu dojrzewania i wczesnej dorosłości, kiedy na plan pierwszy wysuwają się potrzeby o charakterze intymnym, powodujące zainteresowanie indywidualnymi relacjami z osobami płci przeciwnej. Niepełnosprawność sensoryczna czy ruchowa nie należą do grupy nieprawidłowości rozwojowych, które upośledzają funkcje intelektualne, a więc i potrzeby rozwijające się na bazie rozwoju intelektualnego, takie jak np. potrzeba samorealizacji, potrzeba poszukiwania sensu życia, realizacji zadań życiowych dorosłego człowieka według kulturowo akceptowanego modelu, są potrzebami ujawniającymi się u każdego młodego człowieka, także u człowieka z niepełnosprawnością.

Jednak według Janusza Kirenki (2007) niepełnosprawność sprawia, że życie i funkcjonowanie codzienne jest pewną niedogodnością, która wiąże się również z dezorganizacją wszystkich obszarów życia człowieka. Obniżona sprawność i jej bezpośrednie konsekwencje związane z trudnościami w zaspokajaniu większości potrzeb nie są jednoznaczne z obniżonym poczuciem lub brakiem większości potrzeb ludzkich. Do nich należy rozwijająca się szczególnie w okresie dojrzewania potrzeba więzi emocjonalnej $z$ osobnikiem płci przeciwnej oraz potrzeby seksualne, jednak dla wielu ludzi, zwłaszcza z niepełnosprawnością ruchową, ich zaspokojenie bywa bardzo trudne, ale nie niemożliwe. Zbigniew Izdebski (1980) twierdzi nawet, że potrzeby emocjonalno-seksualne u osób z niepełnosprawnością są 
bardziej nasilone niż u ludzi pełnosprawnych. Być może świadomość większych niż u ludzi pełnosprawnych ograniczeń w realizacji potrzeby bliskości emocjonalnej i znalezieniu partnera seksualnego, świadomość mniejszej fizycznej atrakcyjności prowadzi do nasilenia potrzeb emocjonalno-seksualnych. Z praw Yerkesa-Dodsona (Łukaszewski, Doliński 2000) dotyczących siły motywacji i efektywności działania wynika, że dla osiągnięcia celów trudniejszych bardziej korzystna jest motywacja niższa, ale te same prawa mówią też, iż wraz ze wzrostem motywacji do pewnego momentu wzrasta skuteczność działania. Jeśli za siłę motywacyjną uznamy potrzebę, w tym przypadku potrzeby emocjonalno-seksualne, to teza Izdebskiego o wzmożonych potrzebach emocjonalno-seksualnych u osób z niepełnosprawnością wydaje się być uzasadniona.

Zaspokajanie potrzeb seksualnych jest zazwyczaj poprzedzone stworzeniem silnej intymnej więzi emocjonalnej między partnerami, dlatego znalezienie takiego partnera, uzyskanie jego sympatii, aprobaty dla własnego wyglądu fizycznego i cech osobowości staje się sprawą kluczową. Trudności te mogą wynikać nie tylko z ograniczeń anatomicznych, ale także psychologicznych, takich jak: obniżona samoocena, problemy w nawiązaniu kontaktu emocjonalnego powodowane dotychczasowymi negatywnymi przeżyciami, traumatyczne doświadczenie miłości nieodwzajemnionej itp. Andrzej Radomski (2008) zwraca także uwagę na kulturowe uwarunkowanie akceptacji lub jej braku w związkach partnerskich. Są to ograniczenia antropologiczne oparte na utrwalonych wzorcach socjobiologicznej roli męskiej i żeńskiej.

Bazując na tezie Izdebskiego (1970), możemy założyć, że przez proces rehabilitacji wyzwala się dążenie do eliminowania utrudnień związanych z zaspokajaniem potrzeb, a procesy adaptacyjne i kompensacyjne pozwalają na aktywną postawę życiową i działania ukierunkowane przede wszystkim na zdobycie wiedzy, osiągnięcie niezależności finansowej i maksymalne włączenie się do życia, także towarzyskiego, które jest miejscem nawiązywania bardziej intymnych relacji międzyludzkich. Zresztą odbudowa sił motywujących do pełnego uczestnictwa w życiu zawodowym, towarzyskim i działań na rzecz realizacji siebie samego dokonuje się z tym większym sukcesem, im lepsze są rezultaty tak ukierunkowanej aktywności. Coraz częściej realizacja siebie przez takie działania nazywana jest $\mathrm{w}$ psychologii rezyliencją (resilience).

Umiejętność nawiązywania przez osoby z niepełnosprawnością więzi emocjonalnych z innymi osobami, a zwłaszcza pełnosprawnymi, odgrywa dużą rolę w organizacji wewnętrznej, pozwalając na przezwyciężenie trudności i akceptację obniżonej sprawności fizycznej oraz na zrozumienie, że poczucie sensu życia i bezpieczeństwa można uzyskać niezależnie od piękna cielesnego czy możliwości fizycznych. Jednak taka dojrzałość psychiczna osób z niepełnosprawnością nie wystarcza, aby skutecznie zlikwidować bariery społeczne, u podstaw których leżą 
nie do końca uświadomione mechanizmy obronne związane z ochroną własnego „ja” przed dewaluacją poczucia własnej wartości czy też stereotypowe zachowania wobec osób z niepełnosprawnością albo dyskomfort w bezpośredniej komunikacji interpersonalnej. Nie można jednak zapominać, że osoby z niepełnosprawnością - zwłaszcza młode - podobnie jak ich rówieśnicy bardzo szybko przejmują współczesne sposoby komunikowania się, które w ich wypadku chronią przed bezpośrednim doznawaniem niepowodzenia, jeśli rozmówcy przeszkadza niepełnosprawność partnera. Wszechobecny w życiu młodych ludzi Internet jest też coraz częściej używanym narzędziem komunikacji starszego pokolenia, a nawet ludzi w okresie późnej dorosłości. Jeśli do ryzyka bezpośredniego kontaktu dołączymy trudności z przemieszczaniem się osób z niepełnosprawnością (tak jest przy niepełnosprawności ruchowej i wzrokowej), to zawarcie i podtrzymywanie znajomości przez Internet staje bardzo łatwą drogą rozszerzenia relacji interpersonalnych, bezpiecznego poznawania swoich upodobań, cech charakteru, marzeń itp. Oczywiście istnieją zagrożenia wspólne dla wszystkich użytkowników sieci, ale to jest ryzyko zupełnie niezwiązane $z$ niepełnosprawnością.

Komunikacja przez Internet daje partnerom jednakowe szanse, bo to oni decydują, w którym momencie chcą odsłonić się bardziej i pozwolić na poznanie tego, czego jeszcze rozmówca nie wie. Osoby z niepełnosprawnością unikają w ten sposób ryzyka odrzucenia z racji samej niepełnosprawności, kiedy w pierwszym kontakcie dominują emocje związane z oceną atrakcyjności fizycznej, przeświadczenia na temat ograniczonych możliwości osób niepełnosprawnych, emocje wynikające z porównywania do estetycznych wzorców, obawa o akceptację niepełnosprawnego partnera przez najbliższych, którzy w swoich ocenach kierują się stereotypami kulturowymi.

Kirenko (2007) zwraca uwagę na utrudnienia dotyczące nawiązania bliskich relacji emocjonalnych przez osoby z niepełnosprawnością także dlatego, że w społeczeństwie panuje fałszywe przeświadczenie o braku odczuwania przez nich potrzeby bliskości i potrzeb seksualnych, przez co ujawnianie takich potrzeb uznawane jest za co najmniej nieprzyzwoite. Wobec opisanych utrudnień cyberprzestrzeń nie tylko staje się przyjaznym miejscem, w którym można zaspokoić naturalne ludzkie potrzeby, ale także gwarantuje bezpieczeństwo w trakcie podejmowania inicjatywy zmierzającej do ich zaspokojenia.

\section{CYBERPRZESTRZEŃ I KONTAKTY TRADYCYJNE JAKO FORMY ZASPOKAJANIA POTRZEB EMOCJONALNYCH}

Rosnąca popularność portali internetowych jest rezultatem zmian w świadomości zwłaszcza młodych ludzi, dla których granice między rzeczywistością a przestrzenią 
wirtualną zacierają się, ponieważ ich wczesna i intensywna aktywność w cyberświecie powoduje uznanie tego rodzaju obecności za coś całkowicie naturalnego. Ponadto wzrastające tempo życia, wielorakość obowiązków, które mają już małe dzieci uczestniczące w zajęciach np. plastycznych, muzycznych, teatralnych, nauki języka obcego, zmuszają do wykorzystywania dostępnych form szybkiej komunikacji, przemieszczania się (dziś samolotem, a w przyszłości...?), ignorowania odległości przestrzennej. To wszystko jest możliwe dzięki komunikacji internetowej, która nawet imituje obecność rozmówców w tym samym pomieszczeniu i w tej samej strefie czasowej i umożliwia bezpośredni wzrokowy kontakt (Skype). Nic dziwnego, że powstają ciągle nowe komunikatory internetowe i portale społecznościowe, powiększając z dnia na dzień liczbę społeczności wirtualnych. Zjawisko to wzbudza ciekawość wielu badaczy, którzy próbują m.in. odpowiedzieć na pytanie, czy przez Internet można nawiązać satysfakcjonujące relacje emocjonalne, czy relacje te przenoszą się do świata realnego i czy można znaleźć partnera życiowego przez nawiązanie znajomości w Internecie.

Wyjaśnienia powszechności portali społecznościowych i ich popularności wśród ludzi w różnym wieku należy szukać w zestawieniu cech kontaktu bezpośredniego i kontaktu w cyberprzestrzeni. Aaron Ben-Ze'ev (2015) wskazuje na zalety cyberprzestrzeni w porównaniu z przestrzenią komunikacyjną realną. Za główną uznaje komunikowanie się za pośrednictwem komputera, co pobudza wyobraźnię, a jeśli nie udostępnimy rozmówcy obrazu naszej postaci, asekurujemy się przed natychmiastowym odrzuceniem i oceną bazującą na atrybucji zewnętrznej. W pierwszym kontakcie interpersonalnym wygląd fizyczny jest bardzo ważnym elementem ze względu na ukształtowane stereotypy estetyczne i tendencję do przypisywania osobom atrakcyjnym pozytywnych cech osobowości. Ludzie urodziwi są uznawani za bardziej wartościowych i interesujących (Oleszkowicz, Senejko 2013), a efekt „pierwszego wrażenia”, stereotypy społeczne i nieświadomość pewnych tendencji, przez pryzmat których postrzega się wygląd fizyczny i wyciąga wnioski o cechach psychicznych osoby będącej obiektem zainteresowania, powodują, że osoby z niepełnosprawnością mogą mieć słuszne obawy przed odrzuceniem, zanim będą miały sposobność zaprezentować swoje walory pozafizyczne. Kolejną zaletą cyberkontaktu jest to, że nie podlega on kontroli i krytyce osób trzecich, podczas gdy w rzeczywistości opinia człowieka o drugiej osobie może zmienić wzajemny stosunek partnerów interakcji. Brak możliwości patrzenia na rozmówcę z perspektywy osób trzecich pozwala na interakcję bardziej bezpośrednią i intymną.

Bezpośredni charakter relacji internetowych jest widoczny w sytuacji zdobywania wstępnych informacji o drugiej osobie. W świecie realnym nie wypada zadawać niektórych pytań wprost, zwłaszcza tych bardzo osobistych. W sieci takie pytania są zadawane bez skrępowania, a początkowa anonimowość rozmówców ułatwia 
udzielanie szczerych informacji o sobie i dokonanie wstępnej selekcji, czy warto dalej kontynuować znajomość (Ben-Ze’ev 2005).

To, co w klasycznej komunikacji występuje samoistnie, w komunikacji internetowej musi być jednorazowo wykreowane przez zastosowanie umownych znaków. W netykiecie pojawiają się konwencjonalne pytania umożliwiające dokonanie wstępnej charakterystyki rozmówcy, ale źródłem informacji o partnerze może być też sama rozmowa, sposób formułowania wypowiedzi, a w komunikatach pisemnych gramatyczna i ortograficzna poprawność językowa. Powszechnie używane emotikony także stanowią cenne źródło w komunikacji komputerowej, sygnalizując stan emocjonalny rozmówcy (Grzenia 2006). Z kolei w komunikacji bezpośredniej kluczowe znaczenie mają sygnały niewerbalne, dotyczące emocji, nastawienia do rozmówcy, a także kontekst sytuacyjny. Niektóre z tych pozawerbalnych elementów konwersacji można odczytać również podczas kontaktu wirtualnego, ale jeśli nastąpi odrzucenie przez drugą osobę, to jest ono w świecie wirtualnym mniej bolesne, gdyż natychmiast pojawia się perspektywa poznania nowego partnera oraz możliwość wytłumaczenia odrzucenia okolicznościami zewnętrznymi. Poza tym osoba zrywająca kontakt ma mniejsze wyrzuty sumienia, ponieważ wówczas jako mechanizm usprawiedliwiający włącza się świadomość, że to nie był kontakt realny, a osoba doznająca odrzucenia podobnie tłumaczy sobie porażkę. To między innymi sprawia, że obecność w portalach społecznościowych jest dla osób z niepełnosprawnością dość pociągająca, bo mogą chronić swoje „ja” przed bolesnym doznaniem odrzucenia bezpośredniego, a poza tym to oni decydują ile, jak i w którym momencie odsłonić przed rozmówcą i jak się zaprezentować, aby rozwijającą się znajomość uwolnić od stereotypów związanych z oceną człowieka na podstawie jego cech fizycznych.

Pierwsze badania nad cyberzwiązkami zaowocowały przekonaniem, że stworzenie trwałej relacji emocjonalnej za pośrednictwem sieci jest niemożliwe ze względu na ograniczenia w kontaktach online: brak możliwości komunikowania się w sposób niewerbalny, przez co relacje są powierzchowne i nie mogą prowadzić do bardziej intymnych związków. Jednak zwolennicy zawierania znajomości w Internecie zauważyli, że wobec braku sygnałów niewerbalnych mniej znaczące są wskazówki dotyczące wyglądu zewnętrznego, statusu i płci, a użytkownicy sieci rzadziej popadają w schematyczne oceny czy atrybucje dotyczące zachowań innych ludzi. Główną różnicą między komunikacją internetową a tradycyjną jest tempo pogłębiania relacji między partnerami interakcji (za: Grzenia 2006). Wraz z upływem czasu zanika wiele różnic między związkami internetowymi a realnymi i jeśli tylko czas, jaki mogą sobie poświecić partnerzy, jest wystarczający, możliwe staje się rozwinięcie ich związku do poziomu odpowiadającego relacjom interpersonalnym w świecie pozawirtualnym (Whitty, Carr 2009). 


\section{CYBERPRZESTRZEŃ JAKO SATYSFAKCJONUJACY I BEZPIECZNY SPOSÓB ZASPOKAJANIA POTRZEBY BLISKOŚCI I INTYMNOŚCI PRZEZ OSOBY Z NIEPEŁNOSPRAWNOŚCIĄ}

Cyberprzestrzeń jako miejsce wirtualnych spotkań pojawiła się w połowie lat 90. XX wieku i od tego czasu powstają ciągle portale społecznościowe adresowane do różnych grup wiekowych, sprofilowane ze względu na zainteresowania, oczekiwania zawodowe czy towarzyskie. Popularność tych portali nie słabnie, lecz stale wzrasta, mimo że dostęp do niektórych z nich wymaga uiszczenia opłaty.

Przed badaczem zamierzającym dotrzeć do intymnych potrzeb stoi bardzo trudne zadanie, ponieważ ludzie nie mają zwyczaju „obnażania się” przed obcymi i szczególnie nie lubią mówić o swoich niepowodzeniach na polu relacji emocjonalnych czy niezrealizowanych marzeń. Dlatego cyberprzestrzeń i w tej sytuacji staje się dobrym źródłem pozyskiwania w miarę obiektywnych informacji, ponieważ osoby badane chroni anonimowość. Takie otworzenie się przed zupełnie obcym, ale także anonimowym, badaczem może ponadto mieć wartość terapeutyczną przez zwerbalizowanie swoich potrzeb, trudności w ich zaspokojeniu i tym samym identyfikację źródła własnego problemu. Prowadzone pod kierunkiem autorki badania osób z niepełnosprawnością i poruszanie w nich bardzo osobistych wątków nie natrafiły - wbrew uprzednim obawom - na żadne trudności techniczne, a odzew respondentów był za każdym razem bardzo duży. Między innymi były to badania dotyczące seksualności osób z niepełnosprawnością ruchową (Głód 2015) oraz roli Internetu w zaspokajaniu potrzeby nawiązania więzi emocjonalnej przez młodych ludzi z niepełnosprawnością różnego rodzaju (Tomaszewska 2015). Wyniki korespondują z podjętym w niniejszym artykule tematem i pozwalają pokazać nie tylko życzeniowy stosunek badanych osób do możliwości zaspokojenia potrzeb seksualnych, potrzeby miłości i związku partnerskiego, ale także realną ocenę stanu faktycznego z uwzględnieniem ograniczeń, jakie niesie ich własna niepełnosprawność, i możliwości na znalezienie partnera życiowego. Z przeprowadzonych badań (Tomaszewska 2015) wynika, że wśród osób z niepełnosprawnością ruchową, które - wydawałoby się - mogą mieć największe trudności w realizacji potrzeby silnych emocjonalnych relacji partnerskich, 14,3\% jest w związku małżeńskim, 7,1\% - w związku partnerskim, 21,4\% - w separacji lub po rozwodzie, a więc w sumie jest to 42,8\% osób, które doznały bliskości i intymności emocjonalnej z partnerem. Fakt rozstania nie jest miernikiem niepowodzenia, które może być uznawane za rezultat niepełnosprawności, lecz wręcz przeciwnie - może równie dobrze stanowić podstawę do twierdzenia, że przez rozstanie badane osoby chroniły poczucie własnej wartości. Warto też zaznaczyć, że wśród badanych z niepełnosprawnością ruchową dominowały osoby z niepełnosprawnością w stopniu umiarkowanym 
(44\%) i w stopniu znacznym (41,7\%), a więc stopień niepełnosprawności nie ma nic wspólnego nie tylko z nasileniem, ale również z możliwością realizacji intymnych potrzeb emocjonalnych i seksualnych. Mało tego - na pytanie, czy niepełnosprawność ruchowa obniża zainteresowanie własną płciowością i czy obniża atrakcyjność seksualną, zdecydowana większość osób odpowiedziała przecząco, co obrazują poniższe diagramy.

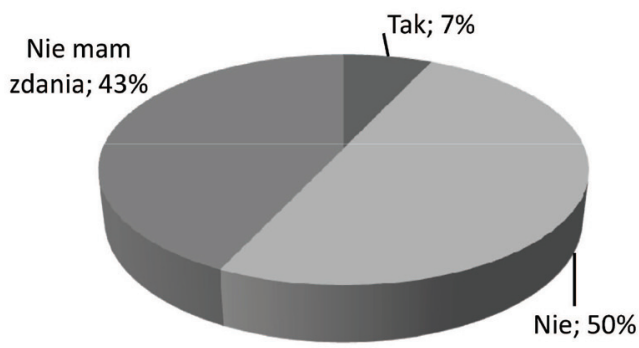

Diagram 1. Odpowiedź na pytanie, czy niepełnosprawność ruchowa obniża zainteresowanie własną płciowością

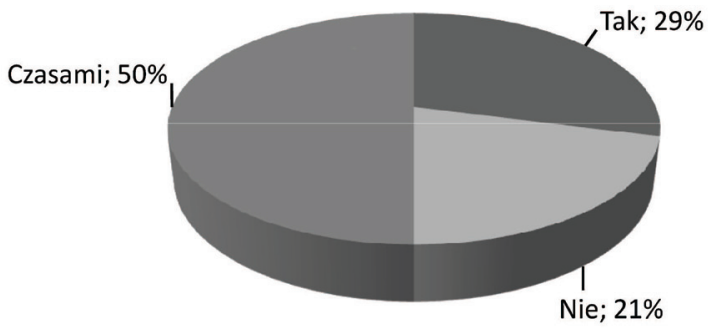

Diagram 2. Odpowiedź na pytanie, czy niepełnosprawność ruchowa obniża poziom atrakcyjności seksualnej w kontakcie bezpośrednim

Czy uważasz, że możliwe jest, aby zakochać się w kimś, kogo znasz się tylko z Internetu?

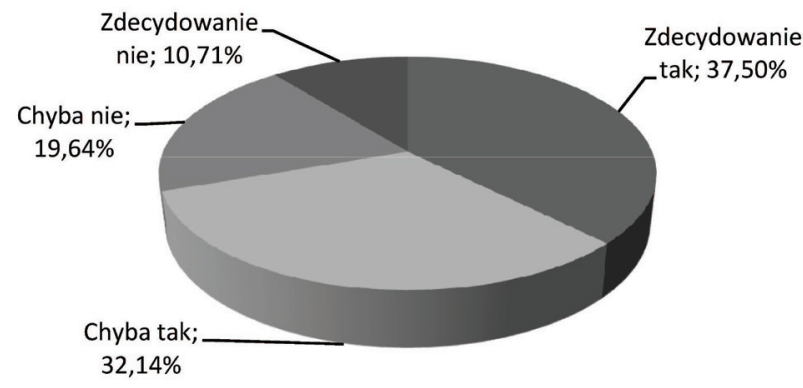

Diagram 3. Ocena możliwości zaspokojenia potrzeby miłości przez Internet 
Z kolei odpowiedzi na pytanie skierowane do osób z niepełnosprawnością różnego rodzaju (Tomaszewska 2015) o to, czy zaangażowanie w relację z osobą poznaną w Internecie może przerodzić się w związek realny, pozwalają zweryfikować hipotezę, że związki internetowe są zawierane dla rzeczywistego zaspokojenia potrzeby miłości i stworzenia relacji intymnych.

Podobnie odpowiedź na bezpośrednie pytanie o możliwość nawiązania w cyberprzestrzeni trwałego związku partnerskiego potwierdza, że intencje użytkowników portali internetowych są precyzyjne.

Czy uważasz, że możliwe jest nawiązanie w Internecie trwałego związku partnerskiego?

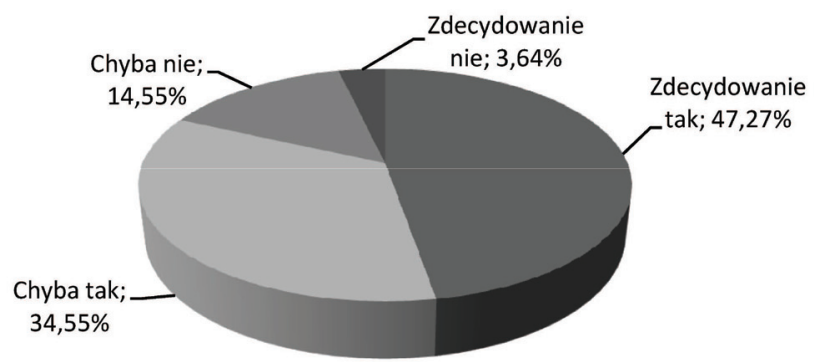

Diagram 4. Ocena możliwości przeniesienia relacji emocjonalnych $\mathrm{z}$ sieci do świata realnego

Komunikacja przez Internet jest także uznawana za dobry sposób poznania życiowego partnera, co obrazuje następny diagram.

Czy zgadzasz się ze stwierdzeniem: Internet jest dobrym sposobem na poznanie przyszłego partnera życiowego?

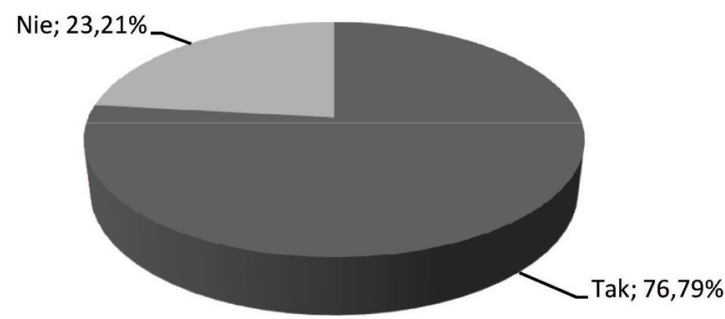

Diagram 5. Komunikacja przez Internet jako sposób poznania partnera życiowego 
Badane osoby mają ponadto duże nadzieje na zaspokojenie potrzeby miłości i intymności w rzeczywistości przez przeniesienie kontaktów wirtualnych do świata realnego, co pokazują dwa kolejne diagramy.

Czy uważasz, że możliwe jest spotkanie przyszłego partnera życiowego w Internecie?

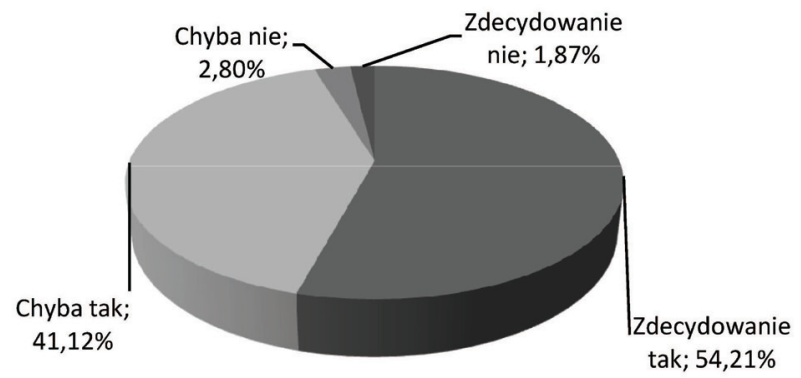

Diagram 6. Ocena możliwości poznania partnera życiowego w Internecie

Czy mógłbyś związać się uczuciowo z kimś, kogo poznałbyś przez Internecie?

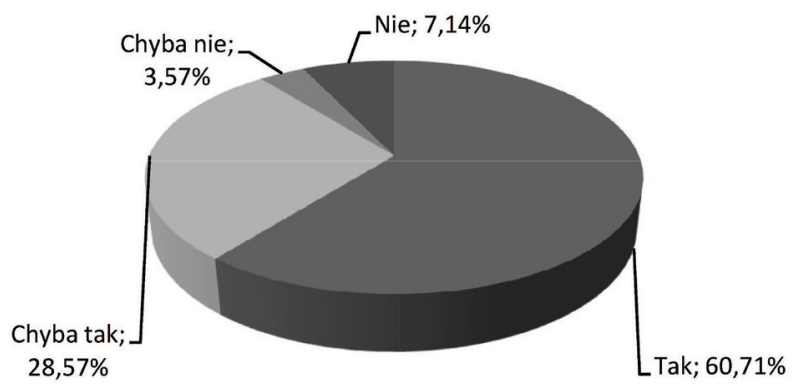

Diagram 7. Emocjonalny stosunek do osób poznanych przez Internet

\section{OCENA STANU INTYMNYCH POTRZEB EMOCJONALNYCH OSÓB Z NIEPEŁNOSPRAWNOŚCIĄ I REFLEKSJE NA TEMAT SPOSOBU ICH ZASPOKAJANIA}

Przedstawione wyniki badań dowodzą, że niepełnosprawność w subiektywnym odczuciu osób nią dotkniętych w żaden sposób nie wpływa negatywnie na potrzeby silnego związku emocjonalnego ani nawiązania relacji intymnych opartych na potrzebach seksualnych. Chociaż niektóre rodzaje niepełnosprawności ograniczają możliwości nawiązania nowych kontaktów interpersonalnych, osoby z niepełnosprawnością radzą sobie $\mathrm{z}$ tym problemem, tak jak ich pełnosprawni rówieśnicy, wykorzystując szeroką ofertę komunikacji komputerowej i to nie tylko z powodu niepełnosprawności. Mają oni wiele podobnych powodów do nawiązywania znajomości przez Internet jak osoby pełnosprawne, odczuwają obawy przed odrzuceniem 
przez potencjalnego partnera i w podobny sposób asekurują się w świecie wirtualnym. Można zatem przypuszczać, że przy wyborze sposobu znalezienia „bratniej duszy" w Internecie dominują te same motywy wśród młodych osób pełnosprawnych i niepełnosprawnych, a fakt niepełnosprawności jest sprawą drugorzędną.

W kontekście przedstawionych wyżej wyników, w których wyraźnie uwidocznia się zaufanie do osób poznanych w sieci i nadzieja na przeniesienie relacji do świata realnego, należy zwrócić uwagę na niebezpieczeństwo rozczarowania wiążące się z taką ufnością. Nie wiemy jednak, czy taka ufność cechuje wszystkich użytkowników Internetu, czy tylko tych, którzy mają ograniczone pole manewru, jeśli w grę wchodzi poznawanie nowych ludzi. Badania porównawcze w tym zakresie zapewne rozwiałyby te wątpliwości.

Istnieje także pewne niebezpieczeństwo dotyczące wszystkich użytkowników sieci zaangażowanych w nawiązywanie znajomości i podtrzymywanie ich za pośrednictwem komputera. Kontakty takie są oceniane przez osoby korzystające z Internetu jako bezpieczne, chroniące przed odrzuceniem, ale także pozwalające na ukrycie niekorzystnych cech swojej osobowości czy wyglądu. W takiej sytuacji istnieje pokusa kreowania siebie według pewnych wzorców uznanych za idealne lub bliskie ideałowi, przy czym również partner komunikacyjny może robić to samo. W rezultacie osoby prowadzące dialog, snujące plany związane z przeniesieniem relacji do rzeczywistości pozawirtualnej mogą doznać ogromnego rozczarowania i poczucia straty czasu albo poczuć się oszukane i wykorzystane przez nieszczerego partnera. Ten lęk przed bezpośrednim kontaktem może także przedłużać w nieskończoność kontynuowanie znajomości przez Internet, tworząc iluzję istnienia bliskości i intymności, podczas gdy de facto czegoś takiego nie ma. Wreszcie intensywna obecność towarzyska w wirtualnym świecie - chociaż posiada zalety - nie może i nie powinna być substytutem rzeczywistych relacji międzyludzkich, a dla młodych ludzi od dzieciństwa oswojonych z przenikaniem się świata wirtualnego i realnego zastępowanie komunikacji bezpośredniej przez internetową może stanowić poważne zagrożenie dla poczucia tożsamości własnej.

\section{LITERATURA}

Ben-Ze’ev A., 2005, Miłość w Sieci. Internet i emocje. Dom Wydawniczy Rebis, Poznań.

Garczyński S., 1972, Potrzeby psychiczne - niedosyt, zaspokojenie. Nasza Księgarnia, Warszawa.

Głód A., 2015, Seksualność osób z niepełnosprawnościa ruchową. Niepublikowana praca magisterska napisana pod kierunkiem J. Konarskiej. UP, Kraków. 
Grzenia J., 2006, Komunikacja językowa w Internecie. Państwowe Wydawnictwo Naukowe, Warszawa.

Izdebski Z., 1980, Miłość i seks, Instytut Wydawniczy CRZZ, Warszawa.

Jundziłł E., 1998, Potrzeby psychiczne dzieci i młodzieży, Wydawnictwo Uniwersytetu Gdańskiego, Gdańsk.

Kirenko J., 2007, Indywidualna i społeczna percepcja niepetnosprawności. Wydawnictwo UMCS, Lublin.

Konarska J., 2003, Niepełnosprawność dziecka jako sytuacja kryzysowa w rodzinie. W: D. Kubacka-Jasiecka, K. Mudyń (red.), Kryzys, interwencja i pomoc psychologiczna. Nowe ujęcia i możliwości. Wydawnictwo A. Marszałek, Toruń.

Konarska J., 2007, Komunikacja interpersonalna osób z niesprawnościa wzroku i narządu ruchu. W: J. Baran, A. Mikrut (red.), Umiejętności komunikacyjne osób $z$ niepetnosprawnością. Teoria, diagnoza, wspomaganie. Wydawnictwo AP, Kraków.

Konarska J., 2008, Inny - nie znaczy gorszy. W: L. Frąckiewicz (red.), Przeciw wykluczeniu społecznemu osób niepetnosprawnych. IPiSS, Warszawa.

Konarska J., 2012, Aktywność komunikacyjna dzieci niewidomych jako warunek ich prawidłowego rozwoju i zapobieganie dystansowi społecznemu. W: M. Parchomiuk, B. Szabała (red.), Dystans społeczny wobec osób z niepełnosprawnościa jako problem pedagogiki specjalnej, t. 1. Wydawnictwo UMCS, Lublin.

Konarska J., 2015, Soziale Auswirkungen von chronischer Krankheit und Behinderung. W: A. Leonhardt, K. Müller, T. Truckenbrodt (red.), Die UN-Behindertenrechts-konvention und ihre Umsetzung. Verlag Julius Klinkhardt, Bad Heilbrunn.

Konarska J., 2017, Znaczenie wczesnodzieciecych doświadczeń emocjonalnych osób $z$ niepetnosprawnościa dla podejmowania wyzwań życiowych. W: B. Winczura (red.), Emocje dzieci i młodzieży z trudnościami w rozwoju i zachowaniu. Impuls, Kraków.

Łukaszewski W., Doliński D., 2000, Mechanizmy leżące u podstaw motywacji. W: J. Strelau (red.), Psychologia. Podręcznik akademicki, t. 2. Gdańskie Wydawnictwo Psychologiczne, Gdańsk.

Maslow A., 1990, Motywacja i osobowość. PAX, Warszawa.

Oleszkowicz A., Senejko A., 2013, Psychologia dorastania. Zmiany rozwojowe w dobie globalizacji. Wydawnictwo Naukowe PWN, Warszawa.

Radomski A., 2008, Antropologia integralna. W kręgu myśli filozoficzno-kulturoznawczej Krzysztofa J. Broziego. Wydawnictwo UMCS, Lublin.

Tomaszewska O., 2015, Rola Internetu w realizacji potrzeby więzi emocjonalnej u młodych osób niepetnosprawnością fizyczną. Niepublikowana praca magisterska napisana pod kierunkiem J. Konarskiej. UP, Kraków. 
Whitty M.T., Carr A.N., 2009, Wszystko o romansie w sieci. Psychologia związków internetowych. Gdańskie Wydawnictwo Psychologiczne, Sopot.

\title{
THE NEED FOR CLOSENESS AND INTIMACY AND DISABILITY AWARENESS
}

\begin{abstract}
The article concerns the aspect of intimate emotional relationships of young people with disabilities. There are described some difficulties in learning the proper emotional relationships with their mothers and other people in early childhood. These difficulties, however, are not directly related to the disability, but rather are the result of parents' reaction to the unusual, and, therefore, not always „clear" for the them, emotional and social reaction of the child. Child's emotional messages are wrongly perceived by other members of society, whose circle expands as the child grows, and this situation contributes to the abnormal emotional and social relationship between the person with a disability and the environment. However, the emotional needs are the same for people with and without disabilities, but in the context of described disturbances in interpersonal relationships, they cannot always be met.

It particularly refers to the need for a close emotional relationship with a person of the opposite sex during adolescence and early adulthood, when these types of needs are particularly intense. The research shows that many young people see a solution to this problem in finding a life partner through the Internet.
\end{abstract}

Keywords: disability, emotional closeness, emotional needs, difficulties in interpersonal relationships 